\title{
INITIATIVE OF PRESIDENT ANDRZEJ DUDA REGARDING THE CHANGE OF THE CONSTITUTION
}

\author{
Bożena Dziemidok-Olszewska \\ Maria Curie-Skłodowska University in Lublin \\ Faculty of Political Science, Department of Political Systems \\ e-mail: bozena.dziemidok-olszewska@poczta.umcs.pl \\ Marta Michalczuk-Wlizło \\ Maria Curie-Skłodowska University in Lublin \\ Faculty of Political Science, Department of Political Systems \\ e-mail: michalczukm@poczta.onet.pl
}

\begin{abstract}
The objective of the article is to present and evaluate the initiative of President Andrzej Duda regarding the amendment of the Constitution, with which he appeared on 3 May 2017. The activities and presentations of the President in this regard during the previous year and related problems were all demonstrated. The controversies regarding the presidential initiative were divided into legal and political. Legal one is the regulation of the institution of referendum in the Constitution of 1997, the political ones result from the opinion and concepts of parties and citizens about the constitution and referendum in its case.
\end{abstract}

Keywords: change of constitution, president, referendum, political science

\section{INTRODUCTION}

During the last year, from 3 May 2017 to 3 May 2018, we witnessed the, still incomplete, process of President Andrzej Duda's activities regarding the referendum on the amendment to the Constitution of the Republic of Poland. The aim of the article is to present and assess the President's activities in this area, and also to demonstrate the reactions to the President's initiative. The research question is the justification, meaningfulness and effectiveness of the presidential initiative; the research hypothesis is the claim that the President's actions are odd and irrational (pointless). 
The issues were divided into two parts: the first one is the registration of the President's speeches and activities, the second covers the problems resulting from the initiative. Due to the topicality of the subject, the article was written on the basis of documents - speeches delivered by President of Poland and media articles posted on websites. The narrowly defined objective and scope of the article meant that the authors did not entertain to recall the concept and theory of amendment to the constitution. The two main methods used during the study are observation and analysis of the content of materials.

\section{POLITICAL FACTS}

President Andrzej Duda announced his initiative to hold a referendum on the changes to the Constitution on 3 May 2017, during the ceremony on the occasion of the Constitution Day of May $3^{\text {rd }}$. At that time, he also expressed his intention to hold a referendum on 11 November 2018, on the centennial of Poland regaining its independence (or to hold it two days long, on November 10 and 11). In his speech at the Castle Square, the President strongly stressed the issue of holding a debate on the constitution with the participation of the public and holding a referendum, which would answer the question in what direction the constitution would be changed. The president said:

Time for a serious constitutional debate, (...) above all with the participation of the Polish nation, (...) not only with the participation of elites and not only with the participation of politicians. (...) In my opinion, as a president, my countrymen have the right to say whether the constitution in Poland has been functioning well for 20 years, whether Poles are satisfied with this systemic model, or whether it requires changes; and Poland and Poles deserve a new constitution [Wystapienie Prezydenta RP z okazji...].

The President closely linked his constitutional initiative with anniversaries, saying that "it is time to start this debate on the $20^{\text {th }}$ anniversary of the constitution, (...) on the $100^{\text {th }}$ anniversary, in 2018 the Polish nation should speak about the political future of its state" [Wystapienie Prezydenta RP z okazji...]. Commentators said that the President, criticizing the Constitution for requiring changes of ailments, called for the development of a new document, providing greater protection for citizens, understood as guaranteeing social security, paying attention to the fate of pensioners and the disabled [Wystapienie Prezydenta RP z okazji...].

On 24 May 2017, in a televised address on the occasion of the second anniversary of the election to the office of president, President Duda announced that

Poland needs a new constitution to develop more efficiently and more effectively so that it can be a state consistent with the will of its citizens, strong, important 
in the international arena, but at the same time close to the society, guaranteeing freedom and equality for citizens [Orędzie Prezydenta RP...].

The president stressed that the directions of changes to the Constitution would for the first time be drafted by the whole society, called on citizens to participate in "this historical task" and "common work" that would be "an expression of our responsibility for the future of the nation and our state". He also stated that the centennial of regaining independence is the best - in his opinion - day to determine the directions of systemic changes in the state, and he will ask the Senate to hold a referendum on 11 November 2018 [Orędzie Prezydenta RP...; Duda: Referendum ws....].

On 25 August 2017, in the historic BHP Hall of the Gdańsk Shipyard, a conference was held, organized by the National Commission of NSZZ "Solidarity", under the slogan "Constitution for citizens, not for elites", which inaugurated the debate on changes to the Constitution. During the speech, President Duda repeated the will to create a new constitution by and for citizens, for the next generation and "the process of actually building a democratic state (...) by remedying the shortcomings that are in the current constitution" [Wystapienie Prezydenta RP podczas...]. The Constitution of 1997 was defined by the President as the "constitution of the transitional period" and the "minority constitution", for which $22 \%$ of total number of citizens actually voted ( 6 million 300 thousand with $52 \%$ turnout), and the civic constitution proposed by "Solidarity" was not put to the vote [Wystapienie Prezydenta RP podczas...]. The President recalled two issues that made him aware of the imprecision of the Constitution. The first is a competency dispute between Prime Minister Donald Tusk and President Lech Kaczyński about who is to represent Poland at the European Council summits in Brussels. The second is raising - in spite of society and without a referendum - the retirement age, and then, the Constitutional Tribunal's decision about the compliance of this regulation with the Constitution. The President expressed hope that the constitutional debate should bring an answer to the question about the scope of the president's and government's competences.

From August 2017 to March 2018, a presidential campaign was conducted to change the Constitution. As part of the campaign, dozens of consultation meetings were held throughout the country, including 18 open regional meetings in all voivodeships [Konstytucja: Referendum...]. At one of them, in Płock, the presidential minister Paweł Mucha argued that the Constitution should be shorter and more precise, 10 questions should be put in a referendum, also formulated on the basis of correspondence and discussions with different circles, questions would concern the directions of political changes, and the aim would be a change that "will be the basis for the functioning of the Polish state for the next decades" [Prezydencki minister...; Okoto 10 pytan...]. The result of the consultations, as stated by Minister Mucha, was the support of the President's idea, and thus a confirmation of the need to change the constitution. 
The campaign included a series of conferences entitled "Together about the Constitution, together about...", during which the President shared his reflections, e.g. that the Constitution does not adequately regulate the division of power, does not take into account the question of participation in the EU and NATO, delineates the competence between authorities [,Czy trójpodziat jest..."] and the introduction of the principle of social market economy into the Constitution of the Republic of Poland called an important and fundamental move, constituting the achievements of "Solidarity" [Prezydent o umieszczeniu...].

On 16 April 2018, a meeting was held to summarize the results of the Constitutional Survey 2017. The questionnaire was commissioned by PiS, constitutionalists invited to take part in it were to answer questions regarding the principles of the Constitution, the status of the individual, the system of government and the judiciary [http://www.polskatimes.pl]. The results of the survey did not yield clear answers, but the majority were in favor of establishing one center of executive power in the form of government and prime minister [http://wiadomosci.gazeta.pl/wiadomosci].

On 26 April 2018, at the National Stadium in Warsaw, the congress "Together on the Constitution at the National" was organized by the Chancellery of the President. It was a summary of the regional meetings regarding the Constitution. President Duda announced the end of the first stage of the pre-referendum debate, and in his speech he spoke about constitutional reform and the related referendum.

In an address on the occasion of the anniversary of 3 May 2018, the President announced that he would apply to the Senate for a nationwide consultative referendum on the Constitution, which would take place on 10-11 November [Ztożę wniosek, aby...]. He did not submit any referendum questions or the scope of matters he would like to put to the vote.

\section{PROBLEMS AND CONTROVERSIES}

At the initiative of President Duda, a number of problems and controversies arise over the conduct of the constitutional referendum. These can be divided into legal, political and logistic. The legal one is primarily the regulation of the referendum institution in the Constitution of 1997, political are related to the opinions and concepts of the party and citizens about the constitution and referendum in its case.

The first issue, having a legal character, is the type or the legal basis for the presidential referendum. President Duda emphatically called it the consultative constitutional referendum. In his speech at the congress "Together on the Constitution at the National”, he said: “(...) a nationwide consultative referendum, is to answer the question whether citizens want to change or pass a new Constitution, and determine the direction of the amendment" [Wystapienie na kongresie...]. According to this statement, the objective of the referendum would not be to change the Constitution itself, but to obtain citizens' opinions on its possible changes and their direction. 
The President would treat the outcome of the referendum as a commitment to come up with the initiative to amend the Constitution in accordance with Article $235^{1}$.

The President would order a referendum pursuant to Article 125 of the Constitution stating that in cases of special significance for the state, the President of the Republic has the right to order, with the consent of the Senate, a nationwide referendum. Article 125, section 3 regulates that the result of the referendum is binding if more than half of those entitled to vote took part in it. Thus, the result of the referendum is consultative, advisory, or non-binding, when the turnout in the referendum is less than $50 \%$ of eligible voters. It should, therefore, be assumed that the participation in the presidential referendum of more than half of those entitled to vote would give a binding result, which would mean the commitment of the Sejm and Senate to change the law accordingly because, as Lech Garlicki stated, "the »resolution « of a nationwide referendum always must be translated into the language of laws or other acts taken by state organs" [Garlicki 2000: 13]. The parliament, however, would certainly have a hard time making such a commitment. In compliance with Article 235, changes to the Constitution are adopted by a two-thirds majority of votes in the Sejm and absolute in the Senate, which in the current political situation does not seem to be possible. In practice, the binding result of the referendum would be difficult to enforce [Konstytucjonalista: $Z$ referendum...].

Another dissonance would arise if the citizens were in favor of adopting a new constitution. The current Constitution does not provide for a procedure for its complete change, so an appropriate law would be necessary.

The most important political controversy is the lack of support for the President's initiative from any political environment, as well as lack of broad social acceptance. The President's proposal to change the Constitution did not meet the approval of the parties represented in the parliament. The ruling United Right with PiS addressed the President's initiative with moderate optimism, the opposition parties - PO and Nowoczesna - definitely rejected the President's initiative, only Kukiz'15 accepted it positively. PiS clearly articulated that it respects the presidential initiative, but is not involved in it and gave it a personal character. PO and Nowoczesna negated the possibility of discussing the change of the Constitution in the situation, as they described it, of its permanent violation, also by the President. Only Kukiz'15 noticed the need for a constitutional debate pointing to its own initiative in this area [Prezydent Andrzej Duda...].

PiS was not involved in presidential activities. The best example of the lack of cooperation was the absence of representatives of the government and party at

1 In the spring of 2018, Paweł Mucha said: "There will be a consultative referendum in which Poles will speak, whether they want to change the constitution, indicating in a few points what these changes should concern. We will treat the results of the referendum as a commitment for the president to come up with the initiative to amend the constitution." Konstytucja: Referendum razem z wyborami. Jakie pytania się pojawia?, Author: PAP / AT, http://www.wnp.pl/parlamentarny/ wydarzenia/konstytucja-referendum-razem-z-wyborami-jakie-pytania-sie-pojawia,30486.html 
the President's congress "Together on the Constitution at the National" (26 April 2018) and full participation of the highest representatives of the government and party during the presentation of the results of the Constitutional Survey 2017 on 16 April $2018^{2}$.

The disputed issue between the President and the ruling PiS is also the preferred system of government. In interviews, Andrzej Duda declared that he was in favor of introducing the presidential system [Czarna polewka...]. He considered it to be more efficient, minimizing competency disputes. Jarosław Kaczyński, who in the past advocated the strengthening the president's position, changed his mind in the second half of 2017.

I openly told President Andrzej Duda that I do not see any premises, with a stable political system, to introduce a presidential system in Poland, which always creates the risk that a person without appropriate political experience, without skills and sometimes - which may happen, but please do not refer it to Mr. Andrzej Duda - a man of ill will, gets a lot of power, and this without real control [Czarna polewka...],

said the leader of PiS in an interview for "Gazeta Polska". It should be remembered that in the constitution and political system presented so far, PiS declared the introduction of a presidential model.

The nature and scope of social participation in meetings organized by the president also formed a controversial point. On 25 August 2017, in the BHP Hall, representatives of PiS, the Chancellery of the President, "Solidarity" and supporters of the ruling party and the President were present [Grochal, Nowa konstytucja...], the issue of participation in constitutional debates was the subject of media information ${ }^{3}$.

Another controversy was and remains the date of the referendum. On 3 May 2017, the president pointed out, primarily for anniversary and patriotic reasons, the 10 and 11 November, and a year later he confirmed this will. PiS politicians did not share the President's opinion and believed that combining independence celebrations with a referendum is not a good idea [Mazurek: Zastanawiamy się...]. Marshal of the Senat, Stanisław Karczewski repeatedly, and always skeptically, spoke about this date and his arrangements with the President [Prezydent spotkat się...], as before, did not bring results.

Conducting a referendum is also associated with expenses and a significant logistic effort. These problems were noticed by the National Electoral Commission, indicating, in addition to finances, a significant burden for the Commission or

2 During the presentation on 16 April, there were, among others: Jarosław Kaczyński, Mateusz Morawiecki, Beata Szydło, Marek Kuchciński, Stanisław Karczewski, Zbigniew Ziobro, Piotr Gliński, as well as the president of the Constitutional Tribunal Julia Przyłębska [http://wiadomosci.gazeta.pl].

3 Minister Mucha said: "There were open regional meetings that anyone could come to. Politicians from PO appeared there, politicians from Nowoczesna appeared, politicians from all parties appeared, local government officials appeared, representatives of non-governmental organizations appeared. These meetings were completely open." Prezydencki minister o zmianie konstytucji: Jeśli naród będzie „,za”, prezydent może przedłożyć projekt [http://niezalezna.pl]. 
the need to create new commissions and other circuits, hours and groups entitled to vote in the referendum and local elections [Referendum ws. Konstytucji...].

The proposal to conduct a constitutional referendum did not meet with a broad support of citizens, either. According to surveys conducted by CBOS in June 2017, the proposal of President Andrzej Duda was strongly supported by $24 \%$ of respondents, 26\% expressed their acceptance (the answer "rather yes"), which gives a total of $50 \%$ [Polacy ocenili propozycje...], 22\% of the respondents voted against the referendum, and $18 \%$ indicated the answer "rather not" (40\%). Every tenth respondent did not have an opinion on this subject. The President's idea gained recognition of the majority of the declared PiS voters (76\%) and those of Kukiz'15 (69\%). PO supporters were mostly against it (71\%). The proposal to hold a consultative referendum on the constitution was supported by the majority of right-wingers ( $72 \%)$, the majority of left-wing supporters criticized it (69\%), as did just above the half of the respondents defining their political views as centrist (51\%).

According to CBOS, $37 \%$ of Poles saw a need to change the Constitution. $15 \%$ decisively supported it, while another $22 \%$ said "rather yes". More $-47 \%$ in total - are opponents of changes, including $21 \%$ of those strongly opposing them, and $26 \%$, who were rather against it. Sixteen percent had no opinion on the need for constitutional reform. CBOS drew attention to the discrepancy between the approval of Poles for the idea of a referendum regarding the directions of systemic changes and a relatively low support for the change of the Constitution. CBOS commentators acknowledged that this may be the result of approval for the very idea of direct democracy and a positive assessment of the President's actions. As noted, the President's initiative "most likely contributed to the fact that in the last three months the percentage of supporters of the amendment to the Constitution increased" [Polacy ocenili propozycję...].

According to a survey conducted in October 2017 by SW Research for the rp.pl website, $38.6 \%$ of the respondents were in favor of amending the basic law, and $37.5 \%$ of respondents said "no" to the changes (with $23.9 \%$ of undecided people) [Referendum ws. Konstytucji...]. A survey conducted in April 2018 at the Ariadna panel for the WP demonstrated that Poles do not want to change the Constitution. Twenty-eight percent of respondents opted for changes, 33\% were against, and 39\% answered "hard to say" [Sondaż. Jeśli już...]. According to the respondents, the President did not reach everyone with his referendum idea, as many as $54 \%$ of the respondents did not hear about Andrzej Duda's initiative.

Surveys show that neither the change in the Constitution nor the referendum were supported by more than half of the citizens, and that - as a result of the campaign - the approval for them did not increase.

During the referendum there may also be problems with attendance. The President stated that the possible weak turnout in the referendum will not be his failure, but the information that Poles do not want changes in the Constitution [Andrzej Duda opowiada się...]. However, he repeatedly called for participation in the referendum, among others, in his speech on 3 May 2018 [Złożę wniosek, aby...]. 


\section{CONCLUSIONS}

The constitutional initiative of President Andrzej Duda allows one to formulate a thesis that it is a peculiar and unconventional action of the head of state. For the first time, the political decision maker did not make any specific proposals, but formed a postulate to change the Constitution and that the nation should take part in the process, indicating whether and how to change it. The President's assessment was limited to finding weaknesses and maladjustments of the Constitution to the current political situation, and expressing the will to change it. So, it was, and still remains, a general initiative that did not contain any clear projects. From 3 May 2017 to 3 May 2018, the President repeated the same issues and postulates.

The President's initiative was called a propaganda political game with the ruling right-wing camp, the aim of which would be to mark an independent and relatively independent position, breaking with the image of a notary of the government [Majmurek, Konstytucyjny...; Lipiński, Prezydent...]. The President's actions can also be seen as an attempt to find a momentous political topic for himself that can focus the attention of parties, the media and citizens. They should also be interpreted as a procedure delegitimizing the current Constitution, which would lead to the adoption of a new one.

After a year of the President's activity, it can be concluded that the initiative was doomed to failure, loses interest and reiterates the same arguments and theses. Two basic conditions for the creation of a constitution have not been met - there is no constitutional "moment", i.e. a breakthrough situation, there is also no broad support of political parties and society.

Tytul: Inicjatywa Prezydenta Andrzeja Dudy w przedmiocie zmiany Konstytucji

Streszczenie: Celem artykułu jest prezentacja i ocena inicjatywy Prezydenta Andrzeja Dudy w temacie zmiany Konstytucji, z którą wystąpił 3 maja 2017 r. Ukazano działania i wystąpienia prezydenta $\mathrm{w}$ tym zakresie $\mathrm{w}$ ubiegłym roku oraz problemy $\mathrm{z}$ tym związane. Kontrowersje dotyczące prezydenckiej inicjatywy podzielono na prawne i polityczne. Prawne to regulacja instytucji referendum w Konstytucji z 1997 r., polityczne wynikają z opinii i koncepcji partii i obywateli na temat konstytucji i referendum w jej sprawie.

Słowa kluczowe: zmiana konstytucji, prezydent, referendum, nauki polityczne

\section{REFERENCES}

1. Andrzej Duda opowiada się za stworzeniem nowej konstytucji, https://www.polskieradio.pl/5/3/ Artykul/1867557,Andrzej-Duda-opowiada-sie-za-stworzeniem-nowej-konstytucji (access: 27.04.2018).

2. Czarna polewka. Jarosław Kaczyński zniszczyt marzenia Andrzeja Dudy, http://www.newsweek. pl/polska/polityka/jaroslaw-kaczynski-w-wywiadzie-dla-gazety-polskiej-o-systemie-przydenckim,artykuly,416859,1.html (access: 26.04.2018). 
3. „Czy trójpodzial jest wystarczający?”. Prezydent o zmianach w konstytucji; https://www. tvn24.pl/wiadomosci-z-kraju,3/prezydent-andrzej-duda-o-konstytucji-w-palacu-prezydenckim,797694.html (access: 26.04.2018).

4. Duda: Referendum ws. zmiany konstytucji 11 listopada 2018 r., http://wyborcza.pl/7,75398,2185 9299,duda-referendum-ws-zmiany-konstytucji-11-listopada-2018-r.html (access: 26.04.2018).

5. Garlicki, L., 2000, Komentarz do art. 125 Konstytucji, [in:] Konstytucja Rzeczypospolitej Polskiej. Komentarz, L. Garlicki (red.), Wydawnictwo Sejmowe, Warszawa.

6. Grochal, R., Nowa konstytucja tylko dla elit PiS, http://www.newsweek.pl/opinie/nowa-konstytucja-tylko-dla-elit-pis-debata-andrzeja-dudy,artykuly,415111,1.html (access: 25.04.2018).

7. Konstytucja: Referendum razem z wyborami. Jakie pytania się pojawia?, Author: PAP/AT, http:// www.wnp.pl/parlamentarny/wydarzenia/konstytucja-referendum-razem-z-wyborami-jakie-pytania-sie-pojawia,30486.html (access: 26.04.2018).

8. Konstytucjonalista: Z referendum ws. konstytucji moga być problemy prawne, http://www. gazetaprawna.pl/artykuly/1071555,referendum-zmiany-konstytucji-2-3-glosow-w-sejmie-bezwzgledna-wiekszosc-senat.html (access: 27.04.2018).

9. Lipiński, Ł., Prezydent sam zastawia na siebie pułapke, https://www.polityka.pl/tygodnikpolityka/kraj/1747114,1,prezydent-sam-zastawia-na-siebie-pulapke.read (access: 02.05.2018).

10. Majmurek, J., Konstytucyjny niewypat prezydenta, http://www.newsweek.pl/opinie/referendum -konstytucyjne-niewypal-prezydenta,artykuly,426723,1.html (access: 02.05.2018).

11. Mazurek: zastanawiamy się, czy termin referendum, który wskazat prezydent, jest rozsadny, https://www.tvn24.pl/wiadomosci-z-kraju,3/rzeczniczka-pis-o-terminie-prezydenckiego-referendum,827289.html (access: 25.04.2018).

12. Około 10 pytań, określających kierunki zmian. Paweł Mucha zdradził szczegóty referendum konstytucyjnego, http://www.polsatnews.pl/wiadomosc/2018-01-12/okolo-10-pytan-okreslajacych-kierunki-zmian-pawel-mucha-o-referendum-konstytucyjnym/ (access: 25.04.2018).

13. Orędzie Prezydenta RP Andrzeja Dudy, http://www.prezydent.pl/aktualnosci/wypowiedzi-prezydenta-rp/wystapienia/art,219,oredzie-prezydenta-rp-andrzeja-dudy.html (access: 25.04.2018).

14. Polacy ocenili propozycje prezydenta Dudy. Będzie referendum?, https://wiadomosci.wp.pl/polacy-ocenili-propozycje-prezydenta-dudy-bedzie-referendum-6135628866476161a (access: 02.05.2018).

15. Prezydencki minister o zmianie konstytucji: Jeśli naród będzie „za”, prezydent może przedłożyć projekt, http://niezalezna.pl/224184-prezydencki-minister-o-zmianie-konstytucji-jesli-narod-bedzie-za-prezydent-moze-przedlozyc-projekt (access: 03.05.2018)

16. Prezydencki minister podat szczegóły referendum. Będzie około 10 pytań, 13 January 2018, https://www.tvn24.pl/wiadomosci-z-kraju,3/mucha-w-referendum-konstytucyjnym-okolo10-pytan,806026.html (access: 25.04.2018).

17. Prezydent Andrzej Duda chce referendum ws. konstytucji. Tylko Kukiz'15 się cieszy, www. newsweek.pl/polska/polityka/prezydent-duda-chce-referendum-ws-zmian-w-konstytucji-rp-,artykuly,409574,1.html (access: 26.04.2018).

18. Prezydent o umieszczeniu zasady spotecznej gospodarki rynkowej w konstytucji-fundamentalne posunięcie, $P A P$, https://businessinsider.com.pl/finanse/zasada-spolecznej-gopodarki-rynkowej -w-konsytucji-andrzej-duda/9hxpgfp (access: 25.04.2018).

19. Prezydent spotkat się z marszatkiem Senatu. „Rozmowa dotyczyła referendum konsultacyjnego ws. zmian w konstytucji”, http://wiadomosci.dziennik.pl/polityka/artykuly/557995,prezydent-andrzej -duda-marszalek-senatu-stanislaw-karczewski-referendum-konstytucyjne.html (access: 05.05.2018).

20. Referendum ws. konstytucji niepotrzebne? Może niczego nie wykazać, https://wiadomosci.wp.pl/ referendum-ws-konstytucji-niepotrzebne-moze-niczego-nie-wykazac-6177710790977665a (access: 26.04.2018). 
21. Sondaż. Jeśli już zmieniać konstytucję, to trzeba wzmocnić prezydenta, https://opinie.wp.pl/ sondaz-jesli-juz-zmieniac-konstytucje-to-trzeba-wzmocnic-prezydenta-6245326230804609a (access: 26.04.2018).

22. Wystapienie na kongresie „,Wspólnie o Konstytucji na Narodowym”, www.prezydent.pl/aktualnosci/wypowiedzi-prezydenta-rp/wystapienia/art,411,wystapienie-na-kongresie-wspolnie-o -konstytucji-na-narodowym.html (access: 02.05.2018).

23. Wystapienie Prezydenta RP podczas konferencji „Konstytucja dla obywateli, nie dla elit”, http:// www.prezydent.pl/aktualnosci/wypowiedzi-prezydenta-rp/wystapienia/art,262,wystapienie-prezydenta-rp-podczas-konferencji-konstytucja-dla-obywateli-nie-dla-elit.htm (access: 25.04.2018).

24. Wystapienie Prezydenta RP z okazji Święta Narodowego 3 Maja na Placu Zamkowym, http:// www.prezydent.pl/aktualnosci/wypowiedzi-prezydenta-rp/wystapienia/art,203,wystapienie -prezydenta-rp-w-czasie-w-swieta-konstytucji-3-maja-na-placu-zamkowym.html (access: 25.04.2018).

25. Ztożę wniosek, aby referendum ws. konstytucji odbyto się 10 i 11 listopada, http://www.prezydent.pl/aktualnosci/wypowiedzi-prezydenta-rp/wystapienia/art,413,zloze-wniosek-aby-referendum-ws-konstytucji-odbylo-sie-10-i-11-listopada.html (access: 07.05.2018).

26. http://www.polskatimes.pl/fakty/a/ankieta-konstytucyjna-2017-sa-wyniki-czas-na-nowa-konstytucje-glos-zabrali-eksperci-prezydent-andrzej-duda-chce-referendum-wideo,13100846/ (access: 26.04.2018).

27. http://wiadomosci.gazeta.pl/wiadomosci/7,114884,23278047,bedzie-spor-miedzy-andrzejemduda-a-pis-partia-chce-ograniczenia.html (access: 27.04.2018). 